\title{
CONSTRUCT INDUSTRIALIZATION STRATEGIC MODEL IN ISLAMIC PERSPECTIVE
}

\author{
Rahman Fauzan \\ Master Industrial Strategic Management, Dosen Politeknik Hasnur \\ Email: onlymusafir@gmail.com
}

\begin{abstract}
Nowaday, there are two strategic perspective in the industialization, that are import subtitution strategic with structural perpective (Sosialism) and eksport promotion strategic with liberal perspective (Capitalism). Eventhough both of them have long been used by many countries, including Indonesia, but they have not been able to make them as the developed countries which have independence of industry and strong economic growth. This research aimed to get industrialization strategy with different perspectives, that is industrialization strategy model in Islamic perspective to create independently and strong economic growth. There are two stages in this research; the first stage is literature study to formulate the main concepts of the industrialization strategy in Islamic perspective. The second stage is to create a model of industrialization strategy ini Islamic perspective based on the formulation from the first stage. From this research showed that there are three goal of Islamic industrialization strategy they are independence, fulfillment of basic needs and defense. This research also can modeled two systems of industrialization strategy in Islamic perspective there are; the model of Industrial Funding Systems, and the model of Interaction between Resources, Industrial Type and Basic Necessities. Both models can describe the Islamic perspective of industrialization strategy in relation to independence, fulfillment of basic needs, and defense of a nation.
\end{abstract}

Abstrak: Saat ini terdapat dua perspektif strategi dalam industrialisasi, yaitu strategi substitusi impor dengan perspektif strukturalis (Sosialisme) dan strategi promosi ekspor dengan perspektif liberalis (Kapitalisme). Meskipun kedua strategi ini telah lama digunakan oleh berbagai negara termasuk Indonesia, namun keduanya belum mampu menjadikan negara-negara tersebut sebagai negara maju yang memiliki kemandirian industri dan pertumbuhan ekonomi yang kuat. Penelitian ini bertujuan untuk memperoleh strategi dengan perspektif yang berbeda, yaitu model industrialisasi perspektif Islam dalam menciptakan kemandirian dan pertumbuhan ekonomi. Terdapat dua tahapan dalam penelitian ini yaitu; tahap pertama adalah kajian literatur untuk merumuskan konsep-konsep utama strategi industrialisasi dalam perspektif Islam. Tahap kedua adalah membuat model industrialisasi perspektif Islam berdasarkan hasil rumusan tahap pertama. Dari penelitian ini diperoleh hasil bahwa tujuan dari strategi industrialisasi Islam ada tiga yaitu kemandirian, pemenuhan kebutuhan pokok dan pertahanan. Juga dapat dimodelkan dua sistem industrialisasi perspektif Islam yaitu; Model Pendanaan Industri Dalam Islam, dan Model Interaksi antara Sumber Daya, Jenis Industri dan Kebutuhan Pokok Masyarakat. Kedua model tersebut dapat menggambarkan strategi industrialisasi perspektif Islam dalam hubungannya dengan kemandirian, pemenuhan kebutuhan pokok, dan pertahanan suatu bangsa.

Kata Kunci: Rancang Bangun, Model, Strategi Industrialisasi, Perspektif Islam, Kemandirian, Pemenuhan Kebutuhan Pokok, Pertahanan.

\section{Pendahuluan}

Industrialisasi merupakan tahapan logis dalam perubahan struktur ekonomi, yang diwujudkan melalui kenaikan kontribusi sektor industri dalam permintaan konsumen, produksi, ekspor, dan kesempatan kerja. Industrialisasi telah dijadikan sebagai ujung tombak dalam proses pembangunan dan pertumbuhan ekonomi yang tinggi dan berkelanjutan. ${ }^{1}$

Dalam persoalan industrialisasi, saat ini terdapat dua pendekatan strategi yang umumnya

1 Tulus Tambunan, Industrialisasi di Negara Sedang Berkembang: Kasus Indonesia (Jakarta: Ghalia Indonesia, 2001).

2 Dani Rodrik, "Development Strategies for The Next Century," dalam Economic Commision for Latin America and The Caribbean (Development Theory at The Threshold of The Twenty-First Century Commemorative Event to Mark The Centenary of The Birth of Raul Prebisch, Santiago, 2001); Tambunan, digunakan, pertama, strategi Substitusi Impor (SI) yang sering disebut dengan istilah inward-looking yang didukung oleh aliran kebijakan Strukturalis. Kedua, strategi Promosi Ekspor (PE) yang sering disebut dengan istilah outward-looking yang didukung oleh aliran kebijakan Neoliberalis. Kedua kebijakan strategi ini memiliki garis-garis besar strategi yang berlawanan atau bertolak belakang satu dengan yang lain. ${ }^{2}$

Industrialisasi di Negara Sedang Berkembang: Kasus Indonesia; Lall Sanjava, "Reinventing Industrial Strategy: The Role of Government Policy in Building Industrial Competitiveness," dalam G-24 Discussion Paper No. 28 (New York and Geneva: United Nations Conference on Trade and Development (UNCTAD), 2004); Mudrajad Kuncoro, Ekonomika Industri Indonesia: Menuju Negara Industri Baru 2030? (Yogyakarta: Penerbit Andi, 2007). 
Tabel 1 Perbandingan Aliran Ekonomi Politik Internasional (Poppy S. Winanti, 2007)

\begin{tabular}{lll}
\hline AKTOR UTAMA & \multicolumn{1}{c}{ LIBERALIS } & \multicolumn{1}{c}{ STRUKTURALIS } \\
\hline TUJUAN & Individu/Perusahaan & Kelas Sosial \\
\hline SIFAT SISTEM & $\begin{array}{l}\text { Bersaing secara bebas, } \\
\text { menguntungkan semua pihak }\end{array}$ & Maksimalisasi kepentingan kelas \\
INTERNATIONAL & $\begin{array}{l}\text { Sekunder, mendukung prasarana } \\
\text { pendukung pasar }\end{array}$ & $\begin{array}{l}\text { Primer, memperjuangkan } \\
\text { kepentingan kelas }\end{array}$ \\
\hline KONSEP KEBIJAKAN & $\begin{array}{l}\text { Bangsa harus membuka sistem } \\
\text { ekonomi terhadap ekonomi } \\
\text { dunia tanpa intervensi }\end{array}$ & $\begin{array}{l}\text { Bangsa yang lemah hrs } \\
\text { menghindarkan diri dari kaitan } \\
\text { sistem kapitalis international. }\end{array}$ \\
\hline \multirow{2}{*}{ TOKOH } & $\begin{array}{l}\text { Adam Smith, David Ricardo, } \\
\text { Keynes, John Stuart Mill }\end{array}$ & $\begin{array}{l}\text { Karl Meotonio Dallerstein, } \\
\text { Gantos, Andre } \\
\text { Gunder Frank, Raul Frebisch }\end{array}$ \\
\hline
\end{tabular}

Sampai saat ini kedua aliran strategi tersebut (SI dan PE) terus menjadi perdebatan dan diskusi yang hangat terkait banyaknya negara yang gagal menggunakannya ${ }^{3}$. Kedua penganut aliran strategi ini memiliki argumen masing-masing tentang kegagalan negara-negara yang menggunakan kedua jenis strategi tersebut.

Menurut Tambunan (2001), Indonesia telah lama menerapkan kedua strategi SI dan PE untuk menjalankan industrialisasinya, namun tidak berhasil mengembangkan industri nasional. Hal ini disebabkan karena Indonesia belum memiliki kemantapan dan kemandirian Industri, sebagaimana dapat dilihat dengan tingkat ketergantungan yang sangat tinggi terhadap impor barang modal, input perantara, bahan baku, dan juga terhadap utang luar negeri ${ }^{4}$. Fakta-fakta yang terjadi berkaitan dengan kejadian-kejadian yang menimpa sistem industri Indonesia pada saat krisis moneter menunjukkan bahwa "sistem industri Indonesia tidak mandiri", sehingga mudah rontok.

Ketahanan dan kemandirian industri menurut Andang Widharta, et.al., (2008), meliputi kemampuan untuk menguasai, mengendalikan dan menjamin keamanan pasokan aspek-aspek penting industri. Persoalan kemandirian sistem industri sangat erat hubungannya dengan persoalan kepemilikan terhadap industri-industri terutama alat-alat produksi, apakah dimiliki pemerintah, individu, atau masyarakat secara umum. Dalam pandangan aliran neoliberalis, kepemilikan

\footnotetext{
${ }^{3}$ Dani Rodrik, "Development Strategies for The Next Century"; Tambunan, Industrialisasi di Negara Sedang Berkembang: Kasus Indonesia; Sanjaya, "Reinventing industrial strategy"; Hyun-Chin Lim, "Globalizing Asia: Towards a New Development Paradigm," Globality Study Journal. Stony Brook University. New York, no. 9 (2007); Kuncoro, Ekonomika industri Indonesia.

4 Tambunan, Industrialisasi di Negara Sedang Berkembang: Kasus Indonesia.

${ }^{5}$ Dani Rodrik, "Development Strategies for The Next Century"; Tambunan, Industrialisasi di Negara Sedang
}

pemerintah adalah sekunder, yakni harus memiliki peran minimal dan swasta harus maksimal (kebebasan pasar), pemerintah hanya sebagai fasilitator dan regulator pencipta kondisi ekonomi yang kondusif untuk investasi dan perdagangan. Termasuk penyediaan infrastruktur dan kemudahan-kemudahan lainnya bagi para pengusaha (swasta lokal maupun asing). Setelah itu, mekanisme pasar diberikan kebebasan untuk menjalankan roda ekonomi. Dalam pendirian pabrik-pabrik di suatu negara sebagai proses awal suatu industrialisasi, individu atau kelompok (swasta) dibebaskan untuk berinvestasi pada semua sektor industri yang ada dan dibiarkan bersaing secara bebas sesuai dengan mekanisme pasar. Sedang bagi aliran strukturalis, peran pemerintah adalah primer (harus dominan). Tidak hanya sebagai fasilitator melainkan mengambil peran aktif dalam proses industrialisasi. Seperti intervensi sektor industri dengan insentif-insentif selektif terhadap industri lokal, nasionalisasi pada sektorsektor industri strategis, proteksi terhadap hasil produk dalam negeri dan terlibat secara pasif terhadap perdagangan bebas bahkan melepaskan diri dari kaitan sistem kapitalis internasional. ${ }^{5}$

Konsep industrialisasi tidak dapat dilepaskan dari permasalahan kebijakan ekonomi dan politik suatu negara ${ }^{6}$. Sedang persoalan ekonomi dan politik suatu negara dilandasi oleh ideologi yang diterapkan oleh negara tersebut ${ }^{7}$. Dari sini kita dapat memahami mengapa kedua pendekatan

Berkembang: Kasus Indonesia; Sanjaya, "Reinventing industrial strategy"; Kuncoro, Ekonomika industri Indonesia.

${ }^{6}$ Kuncoro, Ekonomika industri Indonesia.

7 Taqyuddin An- Nabhani dan Moh. Maghfur Wachid, Membangun Sistem Ekonomi Alternatif: Perspektif Islam (Surabaya: Risalah Gusti, 1999); Dani Rodrik, "Development Strategies for The Next Century"; Abdurrahman al-Maliki, Politik Ekonomi Islam, trans. oleh Ibnu Sholah (Jakarta: Al-Izzah, 2001); Kuncoro, Ekonomika industri Indonesia. 
strategi yang ada selama ini memiliki perbedaan yang signifikan, sebab aliran strukturalis dan strategi SI berlatar belakang ideologi sosialisme sedang aliran liberalis dan strategi PE berlatar belakang ideologi kapitalisme.

Dari pengalaman-pengalaman buruk penerapan strategi-strategi industrialisasi yang ada ini, dan juga semakin tampak jelasnya kegagalan ekonomi kapitalisme yang menjadi sumber kebijakan industrialisasi yang diterapkan dibanyak negara saat ini, mengisyaratkan perlunya usaha mencari suatu alternatif strategi industrialisasi yang baru 8 . Hal ini membuat para peneliti kemudian mencari strategi-strategi lain sebagai alternatif. Hanya saja berbagai penelitian dalam mencari alternatif strategi yang dilakukan saat ini masih berpijak kepada kedua pendekatan strategi yang selama ini telah ada ${ }^{9}$, sehingga belum menyentuh kepada persoalan mendasar yang selama ini belum ditemukan solusinya oleh kedua konsep strategi yang ada tersebut.

Berdasarkan paparan di depan, maka tujuan penelitian ini adalah untuk menemukan model strategi industrialisasi alternatif yang berlandaskan ideologi Islam melalui penelaahan terhadap konsepkonsep Islam di bidang kebijakan politik industri.

\section{Industrialisasi Perpsektif Islam}

Konsep kebijakan industrialisasi dalam Islam masuk dalam kebijakan pertumbuhan ekonomi (kekayaan) negara. Dalam Islam ada dua solusi terhadap obyek ekonomi, pertama, politik ekonomi. Kedua, pertumbuhan kekayaan atau pertumbuhan ekonomi ${ }^{10}$. Politik ekonomi dalam Islam diarahkan untuk menjamin terpenuhinya semua kebutuhan primer (al-hajat al-asasiyah/basic needs) tiap-tiap indvidu, dan memenuhi kebutuhan-kebutuhan sekunder dan tersier (al-bajat al-kamaliyah) sesuai kadar kemampuannya sebagai individu yang hidup dalam masyarakat tertentu yang memiliki gaya hidup khas ${ }^{11}$. Kebijakan ekonomi tidak lain merupakan solusi bagi setiap individu, sehingga mereka dapat berusaha meraih kemakmuran, dengan selalu menjadikan nilai-nilai yang ditetapkan oleh syariat sebagai faktor utama dalam setiap interaksi yang terjadi di antara individu.

Terdapat beberapa kajian yang telah dilakukan terhadap industrialisasi perspektif Islam,

\footnotetext{
8 Tambunan, Industrialisasi di Negara Sedang Berkembang: Kasus Indonesia.

9 Tambunan; Sanjaya, "Reinventing industrial strategy"; Kuncoro, Ekonomika industri Indonesia.

10 al-Maliki, Politik Ekonomi Islam, 39.

11 al-Maliki, 37.
}

diantaranya yang paling dominan adalah yang dikembangkan oleh pemikir-pemikir dan 'ulama Hizbut Tahrir, seperti oleh An Nabhani (1953), Al Maliki (2001), Ismail Yusanto, (2003), Dwi Condro Triono, et.al., (2008) dan Andang Widharta, et.al., (2008). Hizbut Tahrir adalah partai politik Islam internasional yang didirikan oleh Taqiyuddin An Nabhani pada tahun 1953. Tujuan berdirinya adalah berjuang untuk mengembalikan ideologi Islam sebagai solusi bagi berbagai persoalan global di dunia ${ }^{12}$.

Konsep Industrialisasi menurut An Nabhani (1999) dan Al Maliki (2001), haruslah memperhatikan hukum-hukum Islam tentang industri terkait dengan jenis barang yang diproduksinya. Industri, dilihat dari realitas industri itu sendiri merupakan hak milik pribadi. Sebab, industri merupakan barang yang bisa dimiliki secara pribadi. Hanya saja, jenis barang yang diproduksi oleh industri itulah yang merubah status industri tersebut apakah menjadi kepemilikan individu (private property) atau kepemilikan umum (collective property) atau kepemilikan negara (state property). Apabila industri itu dari barang yang diproduksinya merupakan hak milik individu, seperti pakaian, sepatu, mobil, dan yang sejenisnya maka ia dikembalikan kepada individu. Artinya siapa saja boleh memilikinya. Sedangkan jika, barang-barang yang diproduksi tersebut merupakan hak kepemilikan umum, seperti barang tambang logam maupun minyak, atau yang menguasai hidup orang banyak, maka ia tidak boleh dimiliki oleh industri individu, melainkan berupa industri kempemilikan umum yang dikelola oleh negara yang hasilnya dikembalikan sepenuhnya kepada masyarakat umum ${ }^{13}$.

Hukum-hukum industri baik dengan menggunakan mesin ataupun kerajinan tangan tidak akan terlepas dari hukum-hukum pendirian industri (jenis perseroan), ijarah, jual-beli dan perdagangan luar negeri ${ }^{14}$. Selain itu, menyangkut persoalan kepemilikan sektor-sektor industri Islam mengaturnya dengan konsep kepemilikan yang berbeda dengan konsep kepemilikan kapitalisme yang menganut kebebasan kepemilikan individu, ataupun sosialisme yang menganut kepemilikan umum melalui negara ${ }^{15}$.

\footnotetext{
12 Syamsul Arifin, Ideologi dan Praktis Gerakan Sosial Kaum Fundamentalis: Pengalaman Hizb al-Tabrir Indonesia (Malang: Penerbitan Universitas Muhammadiyah Malang, 2005). 13 Arifin.

14 Nabhani dan Wachid, Membangun sistem ekonomi alternatif, 152.

${ }^{15}$ Nabhani dan Wachid, 73-74.
} 


\section{Metode}

Penelitian ini menggunakan dua tahapan, yaitu pertama menemukan konsep-konsep kunci industriliasasi dalam perspektif Islam kemudian merumuskannya dan kedua melakukan rancang bangun model industrialisasinya.

Pada tahap pertama digunakan metode analisa kualitatif dengan menggunakan metode content analysis. Objek penelitian pada tahap pertama adalah kajian literatur dari konsep pemikiran industrialisasi berbasis Islam dari 5 buku utama, yaitu:, Nidzom alIqtishody fi Al-Islam karya Taqyuddin An Nabhani (1999), As-Siyasatu al-Iqtishadiyatu al-Mutsla karya Abdurrahman Al-Maliki (2001), Al Amwal Fi Daulatil Khilafah karya Abdul Qadim Zallum (2002), Nizhomul Hukmi Fi Al-Islam karya Abdul Qadim Zallum (2002) dan Ajhizah ad-Dawlah al-Khilafah karya Hizbut Tahrir (2006).

Dari pemikiran-pemikiran di dalam kitab-kitab tersebut kemudian diolah menggunakan tahapan formulasi model, sehingga diperoleh rumusanrumusan konsep kebijakan yang dapat menjelaskan strategi industrialisasi perspektif Islam.

Tahapan kedua adalah rancang bangun model industrialisasi perspektif Islam, metode rancang bangun yang dilakukan dalam penelitian ini adalah sebagai berikut:

1. Penentuan obyek sistem nyata;

Obyek sistem yang akan dimodelkan adalah rumusan-rumusan dari konsep kebijakan yang terkait dalam penentuan strategi industrialisasi perspektif Islam.

2. Pendekatan sistem (system approach);
a. Tujuan sistem,
b. Batasan sistem,
c. Komponen-komponen sistem,
d. Interaksi antar komponen sistem.

3. Pembuatan model konseptual (conceptual design) sistem industrialisasi perspektif Islam.

\section{Hasil Penelitian}

\section{Perumusan Konsep Strategi Industrialisasi Perspektif Islam}

Melalui kajian literatur yang dilakukan, diperoleh hasil penelitian berupa rumusan kebijakan-kebijakan industrialisasi perspektif Islam. Rumusan konsep pemikirannya digambarakan secara skematik untuk mempermudah pemahaman.

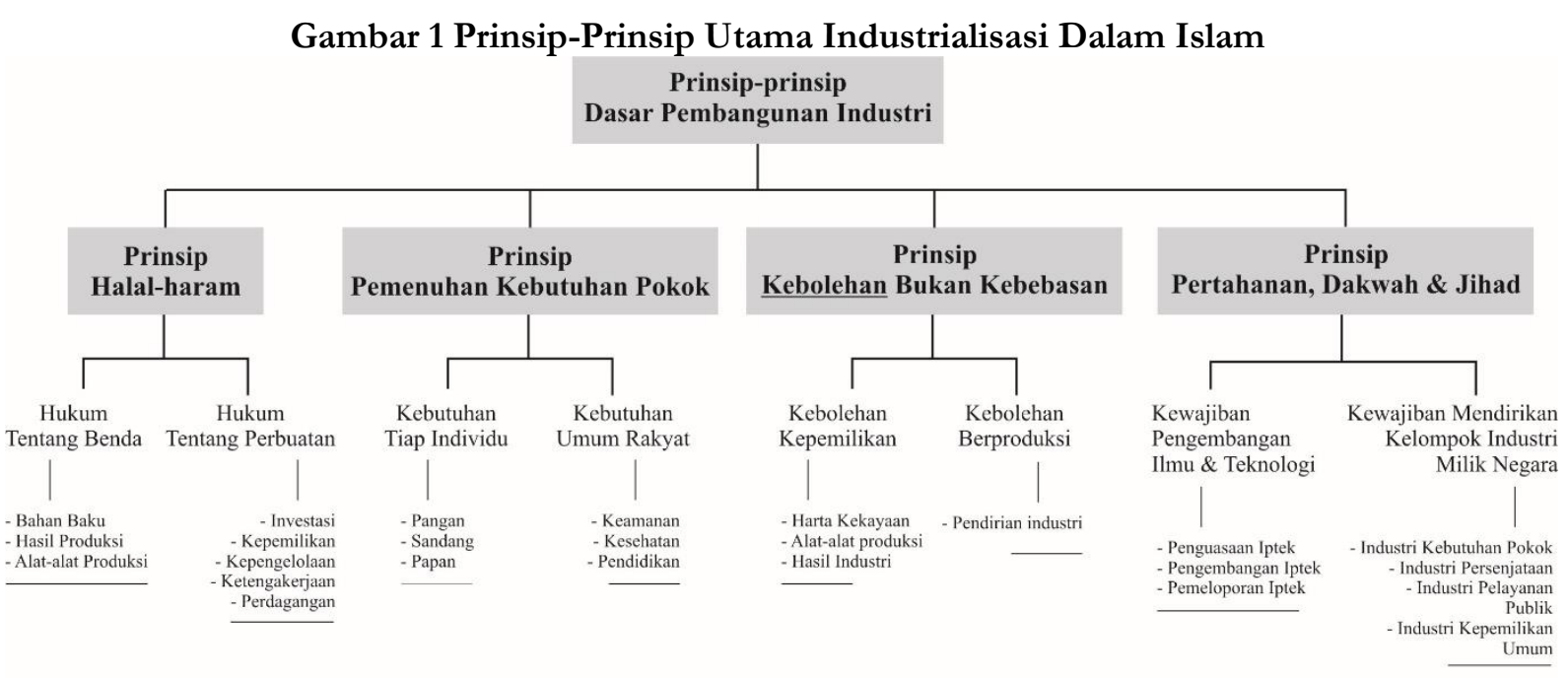

Rumusan konsep yang pertama (Gambar 4.1) menjelaskan tentang prinsip dasar pembangunan industri dalam Islam, terdiri dari 4 prinsip utama yaitu; (1) prinsip halal dan haram, (2) prinsip pemenuhan kebutuhan pokok, (3) prinsip kebolehan bukan kebebasan, (4) prinsip pertahanan, dakwah dan jihad. 


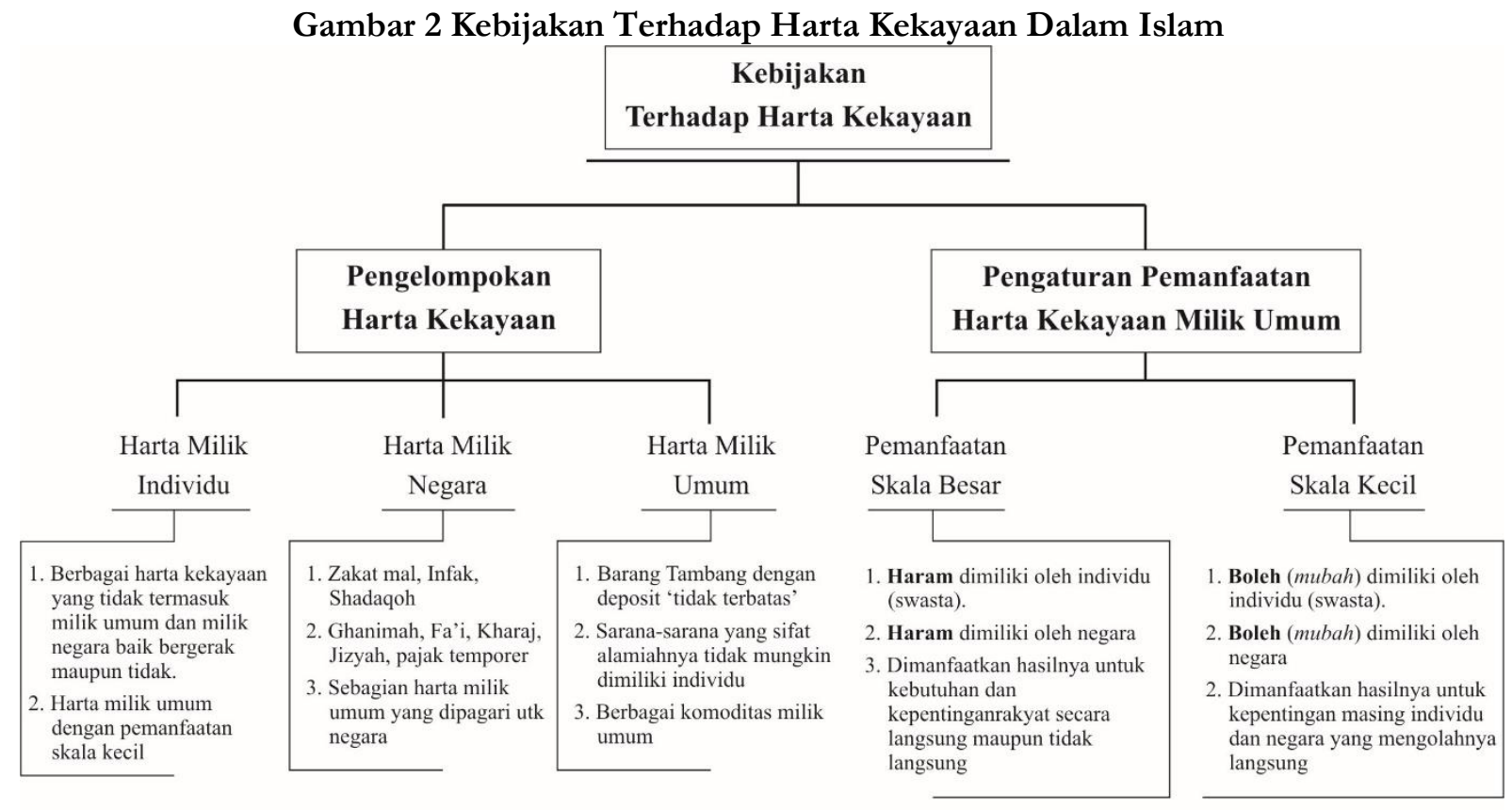

Rumusan konsep yang kedua (Gambar 4.2) menjelaskan tentang kebijakan terhadap harta kekayaan dalam Islam, yang terdiri dari 2 bentuk kebijakan yaitu: (1) Pengelompokkan Harta Kekayaan, (2) Pengaturan Pemanfaatan Harta Kekayaan Milik Umum.

Gambar 3 Kebijakan Kemandirian Kepemilikan Industri Dalam Islam

\begin{tabular}{|c|c|c|}
\hline & $\begin{array}{l}\text { Kebijakan Jenis } \\
\text { Kepemilikan Industri }\end{array}$ & \\
\hline $\begin{array}{c}\text { Industri Milik } \\
\text { Individu }\end{array}$ & $\begin{array}{c}\text { Industri Milik } \\
\text { Negara }\end{array}$ & $\begin{array}{l}\text { Industri Milik } \\
\text { Umum }\end{array}$ \\
\hline $\begin{array}{l}\text { 1. Bahan baku: } \\
\text { - Harta milik pribadi } \\
\text { - Harta milik umum dalam skala kecil } \\
\text { 2. Pemilik adalah warga negara Islam; } \\
\text { Individu (swasta) secara mandiri atau } \\
\text { bersyirkah (badan usaha) } \\
\text { 3. Dilarang dimiliki oleh bukan warga } \\
\text { negara Islam } \\
\text { 4. Contoh Jenis industri: } \\
\text { Industri manufaktur, industri } \\
\text { elektronika, industri kendaraan, industri } \\
\text { pertanian, perikanan, peternakan dan } \\
\text { lain sebagainya }\end{array}$ & $\begin{array}{l}\text { 1. Bahan baku: } \\
\text { - Harta milik negara } \\
\text { - Harta milik umum dalam skala kecil } \\
\text { 2. Pemilik adalah negara dengan Badan } \\
\text { Usaha Milik Negara (BUMN) } \\
\text { 3. Dilarang dimiliki oleh individu } \\
\text { (privatisasi) ataupun swasta Asing } \\
\text { 4. Contoh Jenis Industri } \\
\text { Berbagai Industri berat, Industri } \\
\text { pembangunan infarstruktur dan industri } \\
\text { militer } \\
\text { Dan berbagai industri yang boleh } \\
\text { dimiliki oleh individu boleh dimiliki } \\
\text { oleh negara. }\end{array}$ & $\begin{array}{l}\text { 1. Bahan baku: } \\
\text { - Harta milik pribadi } \\
\text { - Harta milik umum dalam skala besar } \\
\text { 2. Pemilik adalah warga negara Islam } \\
\text { secara umum } \\
\text { 3. Dilarang dimiliki oleh warga negara } \\
\text { secara individu (privatisasi), negara } \\
\text { ataupun swasta Asing } \\
\text { 4. Contoh Jenis Industri } \\
\text { Berbagai jenis industri tambang padat, } \\
\text { cair, dan gas. } \\
\text { Berbagai industri yang mengolah, air, } \\
\text { udara, energi dalam jumlah besar } \\
\text { Berbagai inudustri pelayanan publik }\end{array}$ \\
\hline
\end{tabular}

Rumusan konsep yang ketiga (Gambar 4.3) menjelaskan tentang kebijakan kepemilikan industri dalam Islam, yang terdiri dari 3 jenis kepemilikan industri yaitu: (1) Industri Milik Individu, (2) Industri Milik Negara, (3) Industri Milik Umum. 


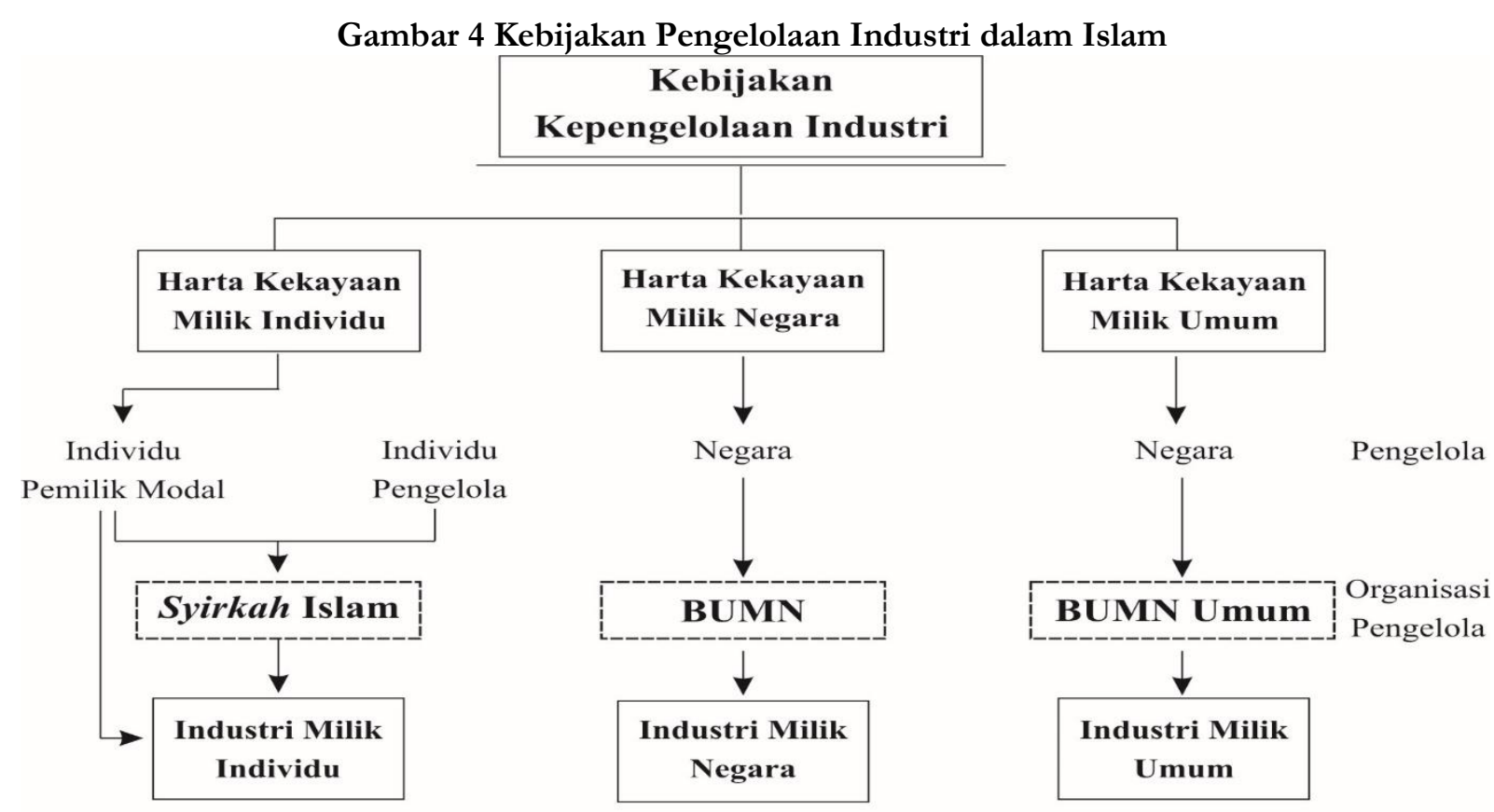

Rumusan konsep yang keempat (Gambar 4.4) menjelaskan tentang kebijakan pengeloaan industri dalam Islam, yang terdiri dari 3 jenis pengelolaan industri yaitu: (1) Industri Milik
Individu dikelola individu, (2) Industri Milik Negara dikelola negara, (3) Industri Milik Umum dikelola oleh negara.

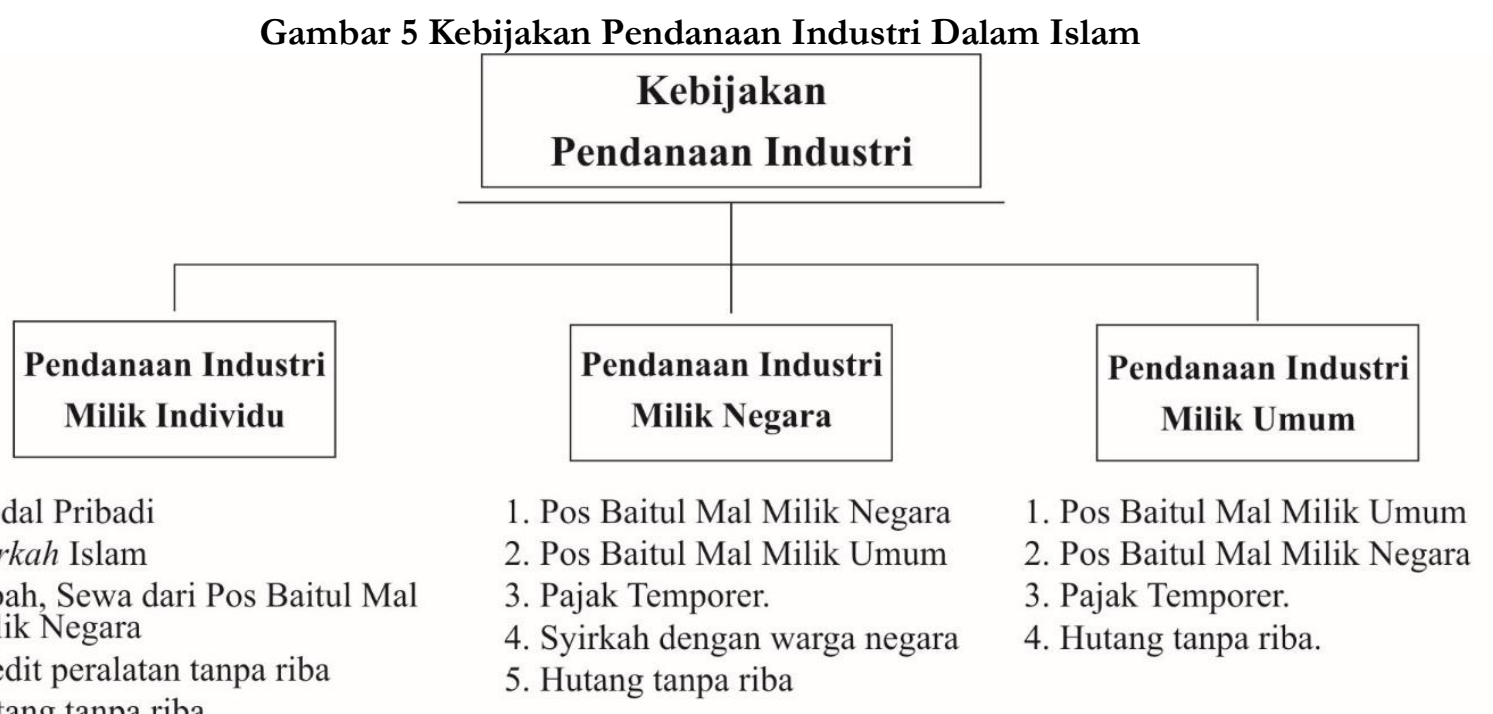

1. Modal Pribadi

2. Syirkah Islam

3. Hibah, Sewa dari Pos Baitul Mal

Milik Negara

4. Kredit peralatan tanpa riba

5. Hutang tanpa riba
1. Pos Baitul Mal Milik Negara

2. Pos Baitul Mal Milik Umum

4. Syirkah dengan warga negara

5. Hutang tanpa riba
Rumusan konsep yang kelima (Gambar 4.5) menjelaskan tentang kebijakan pendanaan industri dalam Islam, yang terdiri dari 3 jenis pedanaan industri yaitu: (1) Pendanaan Industri Milik Individu, (2) Pendanaan Industri Milik Negara, (3) Pendanaan Industri Milik Umum.

Pendanaan industri milik negara dan milik umum dibiayai langsung oleh pos-pos yang ada di Baitul Mal sistem pemerintahan Islam. Pos Baitul mal terdiri dari tiga pos pengaturan keuangan negara, yaitu: pos milik umum, pos milik negara, dan pos milik individu (zakat).
Industri milik umum terdiri dari dua jenis industri, yaitu: industri dengan Badan Usaha Milik Negara (BUMN) Umum dan BUMN. Perbedaan antara BUMN Umum dan BUMN, terletak pada kepemilikan, sumber daya yang diolahnya dan hasil pengolahannya. BUMN Umum mengolah sumber daya milik umum dan dimiliki oleh masyarakat secara umum dengan pengelolaan negara sebagai wakilnya. Hasil dari BUMN Umum seluruhnya harus dikembalikan kepada masyarakat. Sedangkan BUMN mengolah sumber daya milik negara dan dimiliki 
oleh negara yang sekaligus mengelolanya. Hasil dari BUMN adalah milik negara dan digunakan sesuai dengan kebijakannya. Industri milik swasta yang dimaksud adalah industri milik perorangan dan perseroan (syirkab) Islam. Sedangkan komponen pendanaan asing adalah semua komponen dari luar yang terdiri dari Pemerintahan, Industri maupun Individu.

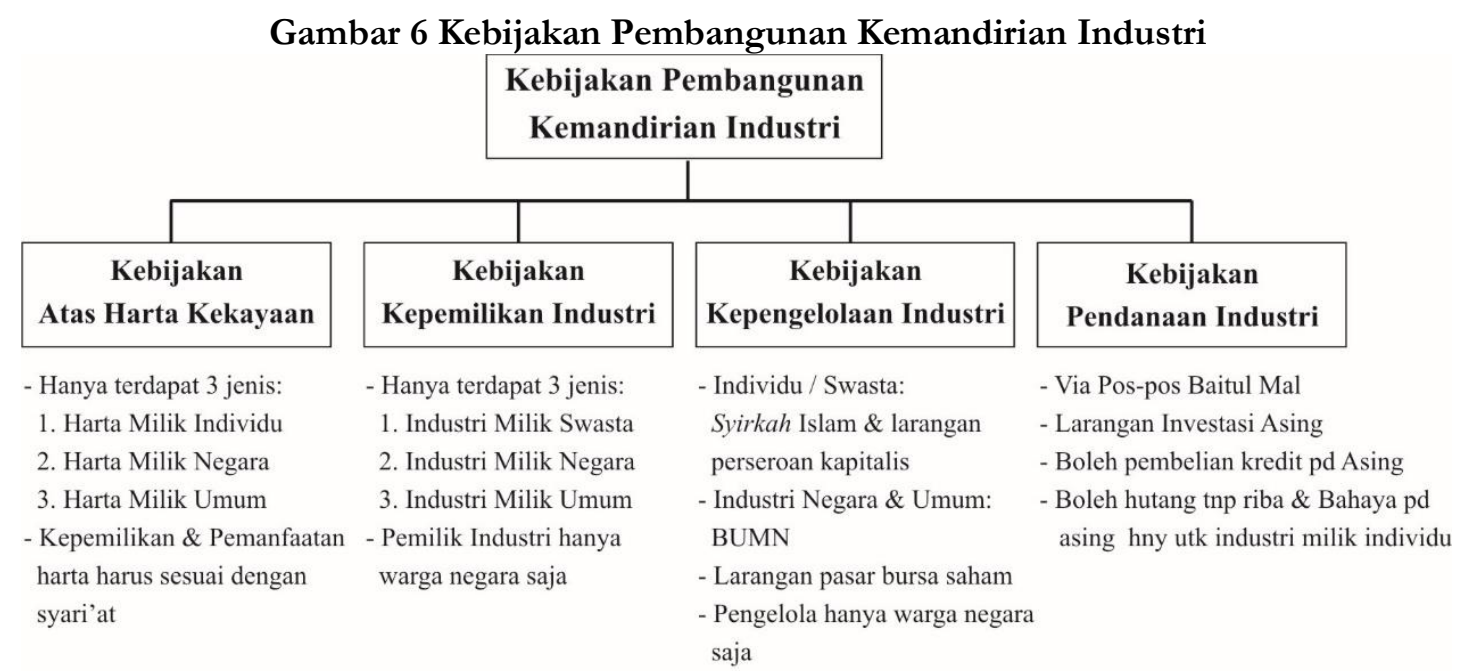

Rumusan konsep yang keenam (Gambar 4.6) menjelaskan tentang kebijakan pembangunan industri dalam Islam, yang terdiri dari 4 jenis kebijakan yaitu: (1) Kebijakan Atas
Harta Kekayaan, (2) Kebijakan Kepemilikan Industri, (3) Kebijakan Kepengelolaan Industri, (4) Kebijakan Pendanaan Industri.

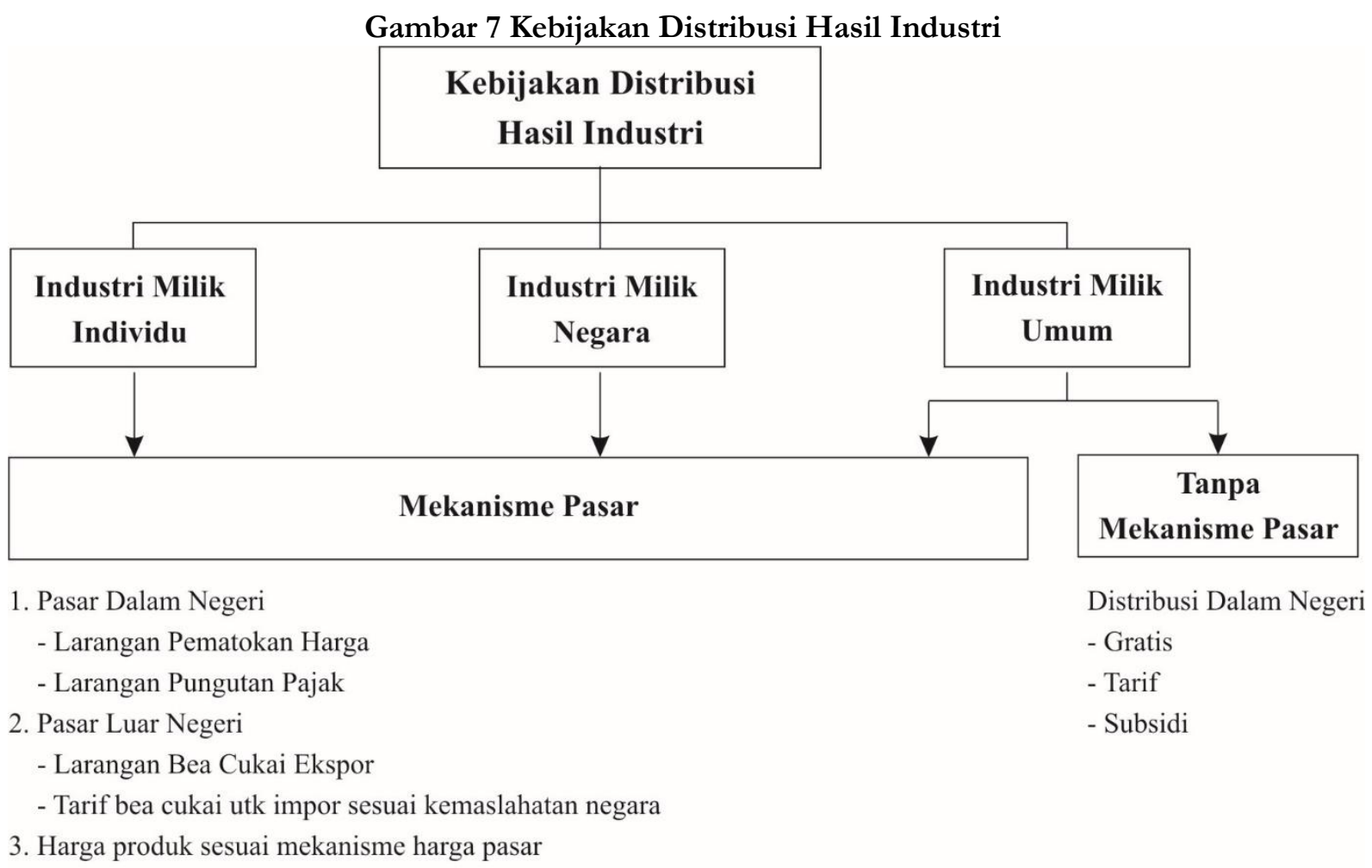

Rumusan konsep yang ketujuh (Gambar 4.7) menjelaskan tentang kebijakan distribusi hasil industri dalam Islam, yang terdiri dari 2 jenis kebijakan yaitu: (1) Mekanisme Pasar, (2) Tanpa Mekanisme Pasar. 


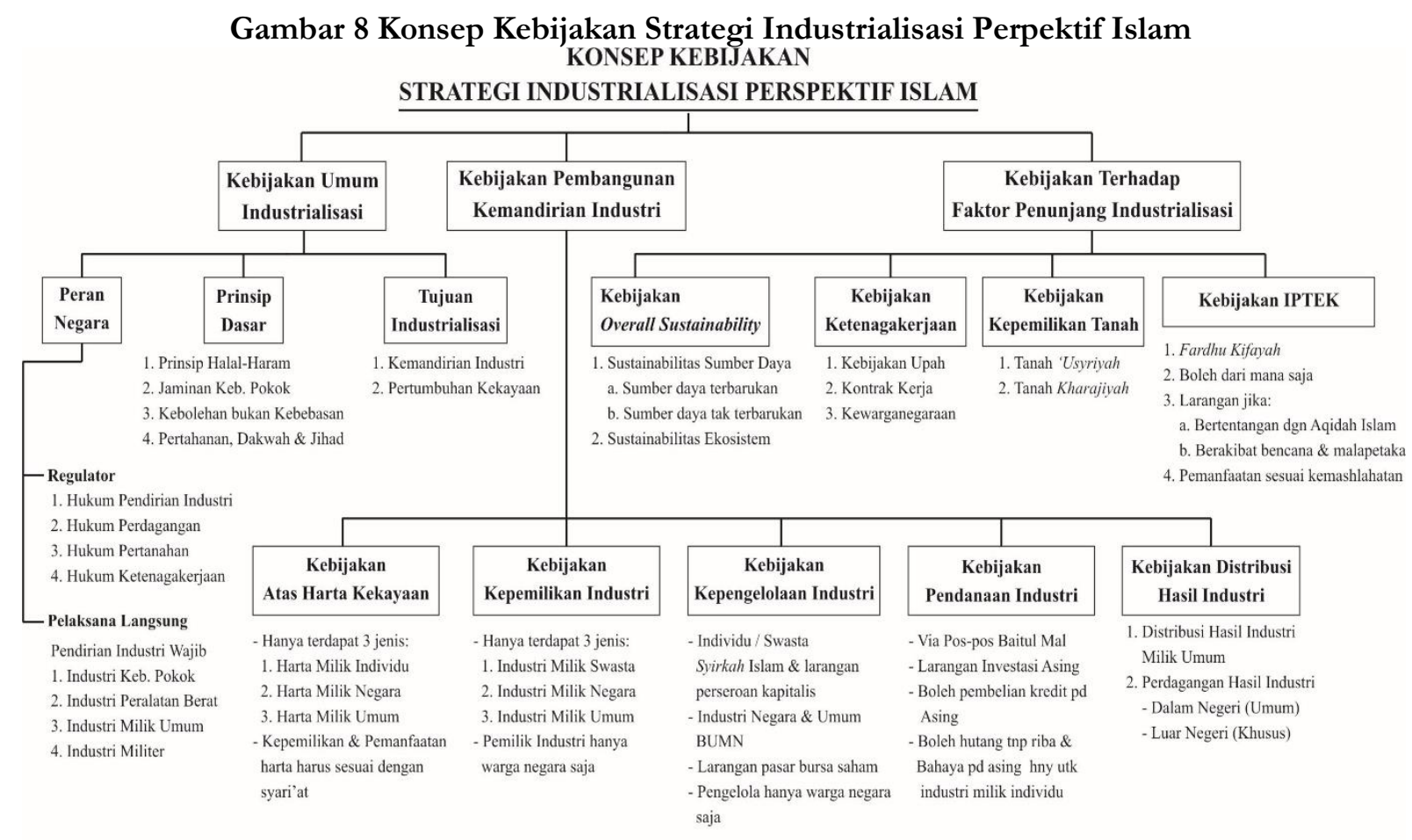

Rumusan konsep yang kedelapan (Gambar 4.8) menjelaskan tentang kebijakan menyeluruh terhadap strategi industrialisasi perspektif Islam, terdiri dari; (1) Kebijakan umum industrialisasi, (2) Kebijakan kemandirian pembangunan industri, dan (3) Kebijakan terhadap faktor pendukung industrialisasi.

Perbandingan konsep strategi industrialisasi persepktif Islam dengan konsep industrialisasi konvensional yang dilaksanakan Indonesia saat ini ditunjukkan pada tabel 5.1. Faktor-faktor utama yang dibandingkan adalah klasifikasi sumber daya (harta kekayaan), klasifikasi jenis industri, kepemilikan, kepengelolaan, pendanaan, dan pemanfaatan (distribusi) hasil industri

Tabel 2 Perbandingan Konsep Industrialiasasi Konvensional (Indonesia) dan Islam

\begin{tabular}{|c|c|c|c|}
\hline No & $\begin{array}{c}\text { Faktor } \\
\text { Pembanding }\end{array}$ & $\begin{array}{l}\text { Industrialisasi } \\
\text { Konvensional }\end{array}$ & $\begin{array}{l}\text { Industrialisasi } \\
\text { Islam }\end{array}$ \\
\hline 1 & $\begin{array}{l}\text { Klasifikasi Harta } \\
\text { Kekayaan }\end{array}$ & $\begin{array}{l}\text { 1. Harta kekayan milik Negara } \\
\text { 2. Harta kekayaan milik individu } \\
\text { (swasta). }\end{array}$ & $\begin{array}{l}\text { 1. Harta kekayaan milik umum. } \\
\text { 2. Harta kekayaan negara } \\
\text { 3. Harta kekayaan individu (swasta) }\end{array}$ \\
\hline 2 & Jenis Industri & $\begin{array}{l}\text { 1. BUMN } \\
\text { 2. BUMD } \\
\text { 3. Perseroan Kapitalis }\end{array}$ & $\begin{array}{l}\text { 1. BUMN } \\
\text { 2. BUMN Umum } \\
\text { 3. Non BUMN (Individu/Syirkah } \\
\text { Islam) }\end{array}$ \\
\hline 3 & Pendanaan Industri & $\begin{array}{l}\text { 1. APBN } \\
\text { 2. Investasi swasta dalam Negeri } \\
\text { 3. Investasi Asing } \\
\text { 4. Pendanaan model kapitalis }\end{array}$ & $\begin{array}{l}\text { 1. POS Baitul Mal } \\
\text { 2. Investasi Swasta dalam negeri } \\
\text { 3. Pendanaan model Islam }\end{array}$ \\
\hline 4 & Kepemilikan & $\begin{array}{l}\text { 1. Kebebasan kepemilikan individu } \\
\text { sesuai mekanisme pasar } \\
\text { 2. Semua jenis industri bebas } \\
\text { dimiliki oleh siapa saja atas dasar } \\
\text { mekanisme pasar. } \\
\text { 3. BUMN boleh diprivatisasi }\end{array}$ & $\begin{array}{l}\text { 1. Kepemilikan Industri ditetapkan } \\
\text { berdasarkan jenis sumber daya } \\
\text { yang diolah. } \\
\text { 2. Negara haram memiliki sumber } \\
\text { daya milik umum. } \\
\text { 3. BUMN haram diprivatisasi }\end{array}$ \\
\hline
\end{tabular}




\begin{tabular}{|c|c|c|c|}
\hline 5 & Kepengelolaan & $\begin{array}{l}\text { 1. Pengelola industri adalah BUMN } \\
\text { dan non BUMN (perseroan } \\
\text { kapitalis). } \\
\text { 2. Semua jenis industri boleh } \\
\text { dikelola oleh siapa saja dengan } \\
\text { mekanisme kerja sama (hulu) dan } \\
\text { ijin usaha (hilir). }\end{array}$ & $\begin{array}{l}\text { 1. Pengelola industri milik Umum } \\
\text { dan Negara wajib dikelola oleh } \\
\text { negara dalam bentuk BUMN. } \\
\text { 2. Industri milik (swasta) individu } \\
\text { dikelola oleh swasta dalam bentuk } \\
\text { syirkah Islam atau perorangan. }\end{array}$ \\
\hline 6 & $\begin{array}{l}\text { Pemanfaatan } \\
\text { (Distribusi) Hasil } \\
\text { Industri }\end{array}$ & $\begin{array}{l}\text { 1. Hasil Industri BUMN di dijual } \\
\text { untuk pendapatan negara dengan } \\
\text { kebijakan harga pasar. } \\
\text { 2. Hasil Industri yang merupakan } \\
\text { kerjasama antara swasta dan } \\
\text { negara dijual sesuai kesepakatan } \\
\text { bersama dengan harga pasar. } \\
\text { 3. Hasil industri milik individu dijual } \\
\text { sesuai mekanisme harga pasar. }\end{array}$ & $\begin{array}{l}\text { 1. Hasil Industri milik Umum wajib } \\
\text { dikembalikan kepada pemiliknya } \\
\text { yaitu masyarakat dengan cara } \\
\text { langsung maupun tidak langsung } \\
\text { (tarif dan harga) sesuai syariat. } \\
\text { 2. Hasil Industri milik negara sesuai } \\
\text { dengan kebijakan khalifah (kepala } \\
\text { negara). Dijual dengan harga } \\
\text { pasar sesuai syariat. } \\
\text { 3. Hasil industri milik individu dijual } \\
\text { melalui mekanisme pasar syariat } \\
\text { Islam. }\end{array}$ \\
\hline
\end{tabular}

\section{Hasil Perancangan Model Strategi Industrialisasi Perspektif Islam}

Berdasarkan rumusan-rumusan konsep strategi industrialisasi yang telah dibuat pada penelitian tahap pertama, diperoleh data untuk pembuatan model, yaitu:

\section{a. Sistem Nyata:}

Skema konsep kebijakan strategi industrialisasi perspektif Islam

b. Tujuan Sistem:

Kemandirian, pemenuhan kebutuhan pokok dan pertahanan (tujuan industrialisasi Islam)

c. Batasan Sistem:

Kebijakan pembangunan industri dan sistem distribusi hasil industri

\section{d. Komponen-Komponen Sistem:}
1) Jenis harta kekayaan
2) Jenis kepemilikan industri
3) Jenis badan pengelola industri
4) Jenis kebutuhan masyarakat
5) Jenis distribusi hasil industri

6) Jenis penyedia dana industri.

e. Interaksi Antar Komponen:

1) Interaksi sumber daya dengan jenis industri (berdasarkan skema pada gambar 4.2, 4.3 dan 4.4)

2) Interaksi penyedia dana industri dengan jenis industri (berdasarkan skema pada gambar 4.5 dan 4.6)

3) Interaksi hasil industri dengan kebutuhan masyarakat (berdasarkan skema pada gambar 4.7).

\section{f. Rancangan Sistem Industrialisasi}

\section{Perspektif Islam}

Rancangan konseptual (conceptual design) strategi industrialisasi perspektif Islam dapat digambarkan dengan 2 model konseptual yang utama yaitu; (1) Model Konseptual Pendanaan Industri-Industri (Gambar 4.8) dan (2) Model Konseptual Pemenuhan kebutuhan masyarakat melalui hasil industri (Gambar 4.9). 
Gambar 9 Model Konseptual Pendanaan Industri Dalam Islam

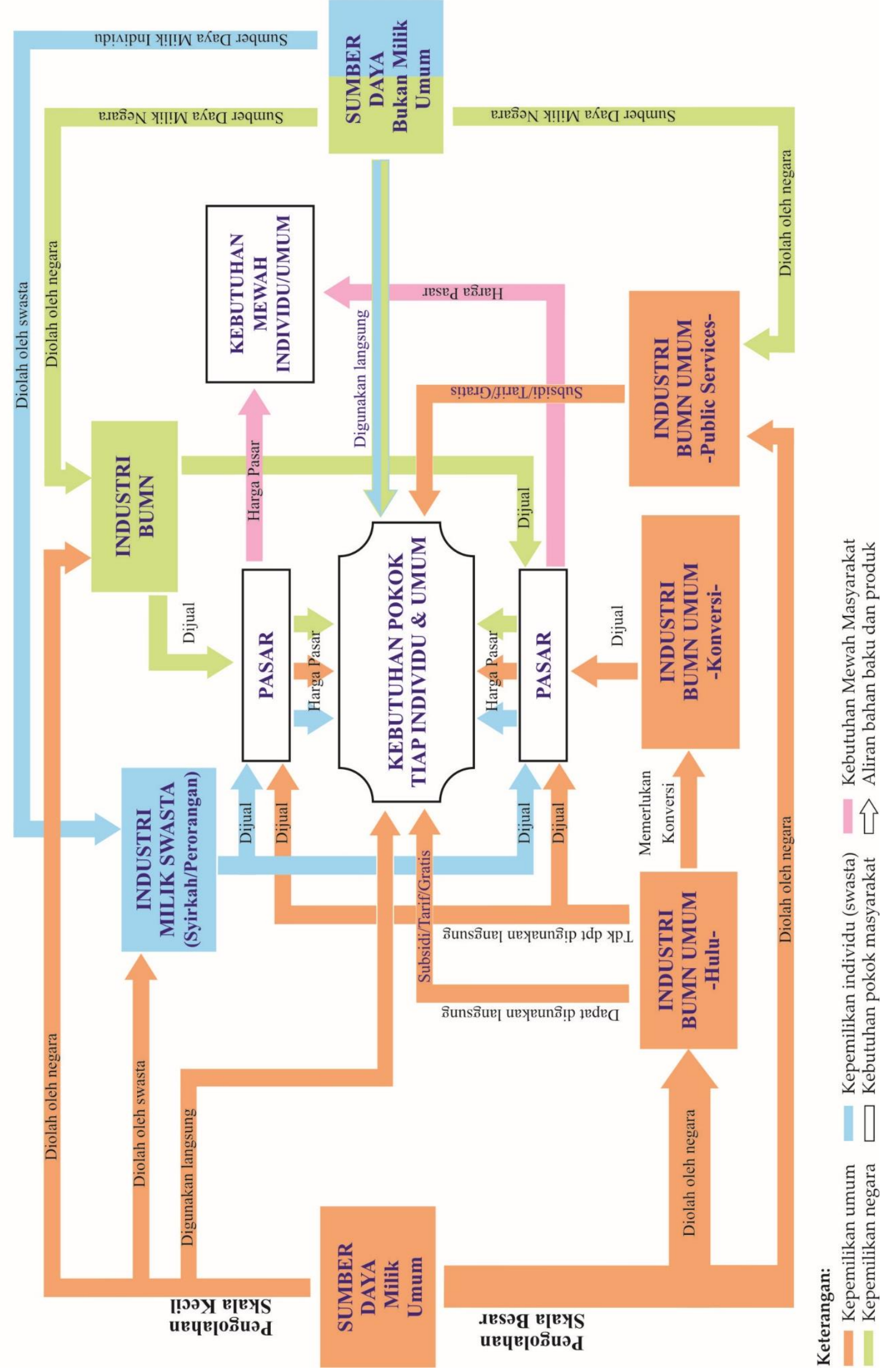




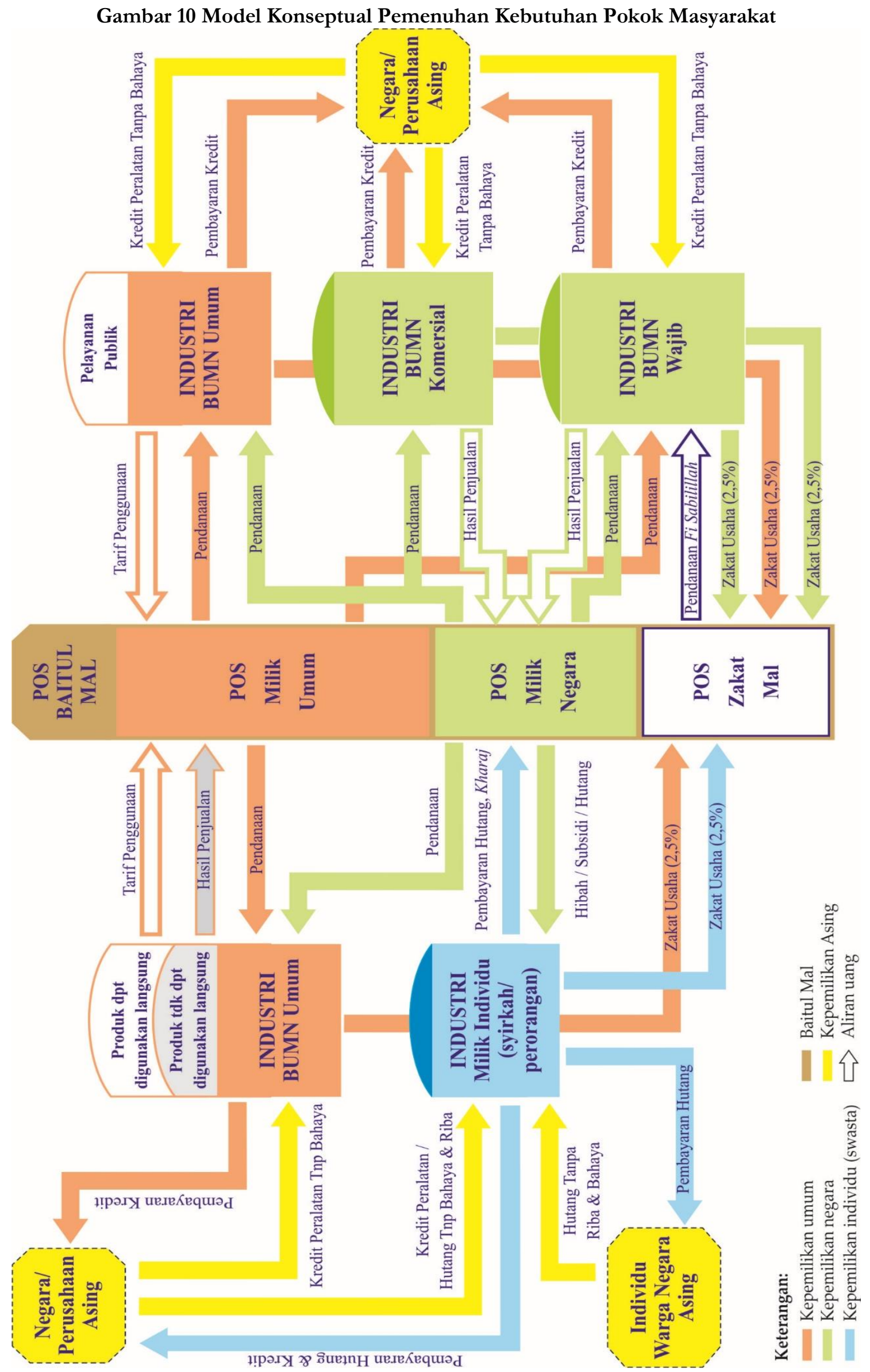




\section{Pembahasan Hasil Penelitian}

Dari hasil pengolahan data yang dilakukan pada penelitian ini diperoleh rumusan konseptual dan model simbolik strategi industrialisasi Islam yaitu:

1. Klasifikasi jenis sumber daya (harta kekayaan) dalam Islam harus dibagi menjadi tiga yaitu, harta kekayaan milik umum, harta kekayaan milik negara, harta kekayaan milik individu. Konsep ini akan menjamin keberadaan sumber daya (berupa raw material dan energi) agar tidak dimonopoli oleh sebagian pihak baik oleh negara ataupun segelintir individu (swasta) saja dan menjamin agar sumber daya tersebut benar-benar dapat terdistribusi keseluruh masyarakat. Dengan kebijakan ini, negara dapat menjamin kemandirian dan pemanfaatan yang maksimal terhadap hasil industri sumber daya alamnya.

2. Konsep ini berbeda dengan kebijakan konvensional yang ada di dunia saat yang membagi sumber daya atau harta kekayaan menjadi dua, yaitu harta kekayaan milik negara dan harta kekayaan milik individu. Dengan kebebasan individu (swasta lokal maupun asing) untuk mengajukan diri dalam pengelolaan harta negara dengan ijin negara. Konsep ini tidak dapat menjamin bahwa harta kekayaan dapat dinikmati oleh setiap masyarakat.

3. Konsep kepemilikan industri di dalam Islam harus diatur sesuai dengan jenis harta kekayaan yang diolah. Sehingga jenis industri di dalam konsep Industrialisasi Islam ada tiga yaitu, industri milik umum, industri milik negara, industri milik individu/swasta (rakyat). Industri milik umum dan negara tidak boleh diprivatisasi (dijadikan milik individu/swasta). Konsep ini menjamin agar industri yang mengolah harta kekayaan milik umum benar-benar dapat dikontrol oleh negara yang mewakili masyarakat untuk mengelolanya, sekaligus menjamin bahwa hasil industrinya dapat dikembalikan untuk kesejahteraan masyarakat secara total dan mampu mewujudkan pertahanan negara. Konsep ini berbeda dengan konsep kepemilikan industri konvensional saat ini yang membagi industri menjadi dua, yaitu industri milik negara/daerah, industri milik individu (swasta). Dalam konsep industrialisasi konvensional, industri-industri milik negara/daerah boleh diprivatisasi, dengan asas kebebasan kepemilikan individu. Konsep ini tidak mampu menjamin kemandirian industri, karena negara tidak sepenuhnya dapat mengontrol industriindustri yang mengolah sumber daya-sumber daya vital milik umum yang telah diprivatisasi tersebut.

4. Konsep kepengelolaan industri dalam Islam adalah berdasarkan jenis industri yang ada. Untuk industri milik umum maka wajib dikelola oleh negara dalam bentuk Badan Usaha Milik Negara (BUMN Umum). Negara hanya bertindak sebagai pengelola saja, sedangkan kepemilikan industrinya adalah milik rakyat secara umum. Untuk industri yang mengelola harta milik negara maka negara memiliki sekaligus mengelolanya melalui BUMN. Industri milik swasta dikelola oleh swasta dengan badan usaha sesuai syirkah dalam Islam atau secara perorangan. BUMN Umum dan BUMN dalam konsep Islam dilarang untuk dikelola oleh swasta. Konsep ini menjamin kemandirian industri negara, karena seluruh kepengelolaan terhadap aset-aset industri dan sumber daya vital dalam kendali penuh negara. Dalam konsep industrialisasi konvensional pengelola jenis-jenis industri adalah Badan Usaha Milik Negara (BUMN) atau Badan Usaha Milik Daerah (BUMD) dan badan usaha perseroan Kapitalis. Ketiga badan usaha ini dapat bekerjasama atau membagi kepemilikannya atas suatu industri melalui kepemilikan saham perusahaan. Industri BUMN atau BUMD ini dalam konsep konvensional Indonesia dapat diprivatisasi oleh swasta nasional maupun asing. Konsep ini tidak dapat menjamin kemandirian industri karena kendali industri tidak sepenuhnya dapat dilakukan oleh negara.

5. Sumber modal/pendanaan (finansial) utama dalam industri-industri perspektif Islam adalah melalui tiga pos dalam Baitul Mal negara Islam (lihat gambar 4.8). Pendanaan industri milik umum wajib didanai oleh negara melalui Baitul Mal pos kepemilikan umum dan pos kepemilikan negara. Kedua jenis industri ini tidak boleh didanai oleh investasi asing ataupun hutang luar negeri. Sedangkan industri milik swasta/individu didanai oleh swasta sendiri dengan ketentuan tidak boleh menerima hutang luar negeri jika berbahaya dan mengandung riba. Konsep pendanaan ini benar-benar akan membuat industri negara menjadi mandiri karena semua industri BUMN Umum maupun BUMN dibiayai melalui kas negara sehingga tidak ada ketergantungan dengan pihak lain (asing). Dalam konsep industrialisasi konvensional, pendanaan industri-industri dilakukan dengan berbagai cara, yaitu pendanaan negara dan daerah, kerja-sama dengan swasta asing dan nasional (perseroan 
kapitalis), penanaman modal asing (PMA), pinjaman lembaga keuangan/bank nasional ataupun asing dengan bunga (riba), pasar bursa saham dan pembiayaan secara individual. Model pendanaan seperti ini menjadikan industriindustri vital negara dapat jatuh ke tangan swasta asing atau terjadinya ketergantungan dengan pihak asing sehingga tidak mampu menciptakan kemandirian industri negara.

6. Pemenuhan kebutuhan pokok masyarakat secara umum dan peningkatan pertumbuhan ekonomi (lihat gambar 4.9) akan dapat diwujudkan dengan konsep kebijakan terhadap distribusi dan pemasaran hasil industrialisasinya. Hasil industri milik umum wajib dinikmati oleh seluruh masyarakat, baik secara langsung (tanpa mekanisme pasar) dengan dibagikan kepada masyarakat melalui kebijakan subsidi dan tarif atau secara tidak langsung (mekanisme pasar) yaitu hasil industri dapat dijual dengan harga pasar kemudian hasil keuntungannya secara keseluruhan harus dikembalikan untuk memenuhi kebutuhan pokok masyarakat. Sedangkan hasil industrialisasi milik negara dan swasta/individu dijual dengan mekanisme harga pasar. Dengan konsep ini, akan menjamin bahwa setiap masyarakat akan dapat menikmati hasil industri dan negara dapat memenuhi kebutuhan pokok rakyat melalui industri BUMN Umum. Masyarakat dapat mengelola dan mengembangkan industri komersial mereka karena hal tersebut tidak dilarang. Dalam konsep konvensional, hasil-hasil berbagai jenis industri yang ada di jual dengan mengikuti harga pasar (mekanisme pasar), baik industri milik negara maupun swasta. Tidak ada jaminan bahwa seluruh hasil industri yang mengelola sumber daya alam milik umum akan dikembalikan kepada rakyat untuk memenuhi kebutuhan pokok umum mereka. Sehingga konsep ini tidak mampu menjamin terpenuhi kebutuhan pokok rakyat secara luas.

7. Kemampuan pertahanan negara akan dapat terpenuhi melalui strategi industrialisasi perspektif Islam ini, sebab Islam mewajibkan seluruh industri strategis untuk pertahanan negara didirikan, dikembangkan dengan pembiayaan yang berasal dari hasil industri BUMN dan BUMN umum.

Dengan enam aspek konsep utama diatas, maka industrialisasi perspektif Islam akan mampu menciptakan kemandirian, pertumbuhan ekonomi sekaligus memenuhi kebutuhan pokok masyarakat untuk mencapai kesejahteraannya.

\section{Kesimpulan}

1. Kebijakan strategi industrialisasi perspektif Islam menunjukkan perbedaan yang signifikan terhadap strategi industrialisasi konvensional yang ada saat ini pada 6 faktor utama yaitu klasifikasi harta kekayaan, jenis industri, pendanaan, pemilikan, pengelolaan dan distribusi hasil industri.

2. Model konseptual pertama (gambar 4.8) yaitu mekanisme pendanaan industri dapat mewujudkan kemandirian industri suatu negara.

3. Model konseptual kedua (gambar 4.9) yaitu mekanisme pemenuhan kebutuhan pokok masyarakat dapat mewujudkan pemenuhan kebutuhan pokok individu (pangan, sandang, papan) dan kebutuhan pokok masyarakat (kesehatan, keamanan, pendidikan).

\section{Rekomendasi}

Untuk penyempurnaan penelitian, masih diperlukan penelitian lanjutan dengan menggunakan data-data kuantitatif agar dapat menunjukkan kinerja dari model strategi industrialisasi perspektif Islam yang telah dirancang bangun, terutama dalam hubungannya dengan tujuan dari strategi industrialisasi Islam dalam memenuhi kebutuhan pokok masyarakat dan kekuatan pertahanan negara.

\section{Daftar Pustaka}

Arifin, Syamsul. Ideologi dan Praktis Gerakan Sosial Kaum Fundamentalis: Pengalaman Hið̌b alTahrir Indonesia. Malang: Penerbitan Universitas Muhammadiyah Malang, 2005.

Dani Rodrik. "Development Strategies for The Next Century." Dalam Economic Commision for Latin America and The Caribbean. Santiago, 2001.

Kuncoro, Mudrajad. Ekonomika Industri Indonesia: Menuju Negara Industri Baru 2030? Yogyakarta: Penerbit Andi, 2007.

Lim, Hyun-Chin. "Globalizing Asia: Towards a New Development Paradigm." Globality Study Journal. Stony Brook University. New York, no. 9 (2007).

Maliki, Abdurrahman al-. Politik Ekonomi Islam. Diterjemahkan oleh Ibnu Sholah. Jakarta: Al-Izzah, 2001.

Nabhani, Taqyuddin An-, dan Moh. Maghfur Wachid. Membangun Sistem Ekonomi Alternatif: Perspektif Islam. Surabaya: Risalah Gusti, 1999.

Sanjaya, Lall. "Reinventing Industrial Strategy: The Role of Government Policy in Building Industrial Competitiveness." Dalam G-24 Discussion Paper No. 28. New York and 
Geneva: United Nations Conference on Trade and Development (UNCTAD), 2004.
Tambunan, Tulus. Industrialisasi di Negara Sedang Berkembang: Kasus Indonesia. Jakarta: Ghalia Indonesia, 2001. 